\title{
Performance of popcorn introductions for agronomic characters, grain yield and popping qualities in the forest and derived savannah agro-ecologies of Nigeria
}

\author{
Oloruntoba OLAKOJO ${ }^{1,2}$, Gbadebo OLAOYE ${ }^{1}$, Adewole AKINTUNDE ${ }^{3}$
}

Received April 25, 2019; accepted August 14, 2019.

Delo je prispelo 25. aprila 2019, sprejeto 14. avgusta 2019.

Performance of popcorn introductions for agronomic characters, grain yield and popping qualities in the forest and derived savannah agro-ecologies of Nigeria

Abstract: The study focus on the evaluation of popcorn lines for their yield and agronomic potentials. Genetic materials were evaluated under irrigation in a three-replicate in a Randomized Complete Block Design (RCBD) with a commercial variety as check. Two seeds were planted per hole using tworow plots of $5 \mathrm{~m}$ long with inter and intra-row spacing of $0.75 \mathrm{~m}$ x $0.5 \mathrm{~m}$, respectively in two locations viz: Ibadan and Ikenne representing the forest and savannah agro-ecologies of Nigeria respectively. Genotypes $(\mathrm{G})$ differed significantly $(\rho \leq 0.01)$ for almost all the characters measured except for ear aspect. Location (L) as well as G x L interaction effects were also well pronounced on all agronomic characters measured except for days to silking and ears per plant. Popcorn 33-1-Y, large pearl shaped, Popcorn 40-Y and Popcorn 34-Y were high yielding with a potential of above $2.0 \mathrm{t} \mathrm{ha}^{-1}$. These materials were found to be fairly resistant to major foliar diseases of the tropical humid ecologies. They are recommended for further evaluation across different agro-environments for possible propagation by popcorn farmers in Nigeria to boost production.

Keywords: grain yield; introductions; popcorn; popping; forest; derived; savannah; Nigeria
Predstavitev uspešnosti uvajanja pokovke na osnovi njenih agronomskih lastnosti, pridelka zrnja in kakovosti nabrekanja $v$ gozdnih in prehodno-savanskih agroekosistemih Nigerije

Izvleček: Raziskava je bile osredotočena na ovrednotenje linij pokovke glede na njen pridelek in agronomske lastnosti. Genetski material je bil ovrednoten ob namakanju $\mathrm{v}$ naključnem bločnem poskusu s tremi ponovitvami $\mathrm{v}$ primerjavi s komercialno sorto. Po dve semeni sta bili posejani v vrstah na ploskvah dolžine $5 \mathrm{~m}, \mathrm{z}$ medvrstno razdaljo $0,75 \mathrm{~m}$ in znotrajvrstno razdaljo $0,5 \mathrm{~m}$, na lokacijah Ibadan in Ikenne, ki predstavljata gozdne in prehodno savanske agroekosisteme Nigerije. Genotipi $(G)$ so se značilno razlikovali $(\rho \leq 0.01) \mathrm{v}$ skoraj vseh merjenih lastnosti z izjemo storža. Vplivi lokacije (L) kot tudi medsebojni vpliv lokacije in genotipa so se dobro izrazili $\mathrm{v}$ vseh merjenih agronomskih lastnostih $\mathrm{z}$ izjemo dni do lasenja in števila storžev na rastlino. Linije pokovke Popcorn 33-1-Y, Large Pearl Shaped', Popcorn 40-Y in Popcorn $34-Y$ so imele velik pridelek, s potencialom čez $2.0 \mathrm{t} \mathrm{ha}^{-1}$. Te linije so bile tudi sorazmerno dobro odporne na večino listnih bolezni, značilnih za vlažne tropske razmere. Priporočamo jih za nadaljne ovrednotenje $\mathrm{v}$ različnih pridelovalnih okoljih za nadaljne razmnoževanje pri pridelovalcih pokovke v Nigeriji za povečanje njene pridelave.

Ključne besede: pridelek zrnja; introdukcija; pokovka; nabrekalne lastnosti; gozd; prehodna savana; Nigerija

1 University of Ilorin, Department of Agronomy, Nigeria

2 Corresponding author, e-mail: tobaolakojo@yahoo.com

3 Obafemi Awolowo University, Institute of Agricultural Research and Training, Nigeria 


\section{INTRODUCTION}

Popcorn (Zea mays L. everta) is a special type of flint maize that has the ability to pop into consumable flakes when heated due to the thickness of the endosperm. The kernel pops upon heating as a result of the unique quality of the endosperm that makes it resist the steam pressure generated until it reaches explosive proportion (Acquaah, 2007). It is one of the most widely used groups of maize all over the world including in Nigeria (Mani and Dadari, 2003). Its demand has increased sharply from mid-seventies, stimulating production of the crop in some areas of the Nigeria's savannas and few other metropolitan cities (Iken, 1993). Popcorn varieties exist in various sizes and colour, it yields are lower, usually about half that of maize hybrids (Ziegler et al., 1984) which may be as a result of the small kernel size or its mass.

Popcorn growth requirements are similar to those for dent corn and the cultural practices for both breed of corn are the same except for some minor modifications in respect of popcorn. Ziegler (2001) noted that such modifications may have to do with timely planting due to the slow germination of popcorn and harvest maturity to enable optimum popping ability. Broccoli and Burak (2004) reported high significant differences $(\rho \leq 0.01)$ for all characters evaluated except kernel density before expansion among fourteen (14) popcorn hybrids evaluated in two years across three environments. Genotype $\mathrm{x}$ Environment ( $\mathrm{GxE}$ ) interaction was also observed to be significant for the two main traits (yield and expansion volume) while the relationship between grain yield and expansion volume was negative. However, a strong and positive association was observed between expansion volume and kernel thickness, suggesting that this trait can be taken as a morphological variable which influence the expansion volume.

$\mathrm{Oz}$ and Kapar (2011) also evaluated 18 single cross popcorn hybrids and four commercial popcorn cultivars for yield and quality traits over three cropping seasons (2006, $2007 \& 2008)$. They reported that the genotypes differed significantly $(\rho \leq 0.01)$ for grain yield, plant height, tasseling time, grain moisture, $\%$ of unpopped kernel and popping volume. The study identified 10 single cross hybrids ('TCM-05-01', 'TCM-05-02', TCM-0503, TCM-05-04, TCM-05-05, TCM-05-06, TCM-05-09, TCM-05-10, and TCM-05-12) with high grain yield and quality traits superior to those of their commercial cultivars. In their own study, Derera et al., (2014) investigated the popping ability of $119 \mathrm{~F}_{1}$ hybrids and one standard check using two popping methods viz: microwave and hot air methods. Although the study revealed that popping quality does not depend on the method adopted for popping, the authors reported significant $(\rho \leq 0.01)$ variability among the hybrids for popping quality traits (flake volume, popping fold, unpopped kernels and grain moisture) which indicated prospect for selection of hybrids with good popping ability. They further reported preponderance of additive gene action for all popping quality traits, thereby creating an opportunity to effectively improve these traits through selection.

The initial step in achieving improvement in popcorn yield and quality attributes is to evaluate the existing germplasm for their agronomic performances and yield potentials as well as popping attributes. The objectives of this study therefore, were to: (i) assess 19 popcorn lines for yield, phenotypic attributes, reaction to prevailing pests and diseases and (ii) identify superior lines that could be used for the development of commercial hybrids for the popcorn industry, thus enhancing popcorn productivity.

\section{MATERIALS AND METHODS}

The experimental materials which comprised nineteen (19) popcorn lines and a commercial variety as check (Table 1) were evaluated under irrigation using a Randomized Complete Block Design (RCBD). The plot size was two (2) rows, $5 \mathrm{~m}$ long with inter and intra-row spacing of $0.75 \times 0.5 \mathrm{~m}$, respectively, replicated three (3) times. The trials were established using two (2) seeds per hole at two (2) locations viz: Ibadan (Longitude $7^{0} 22^{\prime} \mathrm{N}$ Latitude $3^{0} 50^{\prime} \mathrm{E}$ ) and Ikenne (Longitude $6^{\circ} 53^{\prime} \mathrm{N}$ Latitude $\left.3^{0} 42^{\prime} \mathrm{E}\right)$. Fertilizer application was carried out 3 weeks after planting (WAP) at the dosage rate of $180 \mathrm{~kg} \mathrm{ha}^{-1}$ of NPK 20-10-10 and was top-dressed with $100 \mathrm{~kg} \mathrm{ha}^{-1}$ of urea 2 weeks before anthesis. Weed control was done chemically with the application of $51 \mathrm{ha}^{-1}$ pre-emergence herbicides (5 grams per litre Metolachlor and 170 grams per litre Atrazine a.i). Two supplementary hoe-weedings at 6 and 10 WAP, respectively were carried out to keep the field clean of weeds. Agronomic data and disease rating (under natural infestation) were recorded on each line from each replication. Data on days to tasseling and silking; plant and ear aspects as well as husk cover using $1-5$ rating where $1=$ excellent, $2=$ very good, $3=$ good, $4=$ fair and $5=$ poor, were collected on whole plot basis. Plant and ear heights $(\mathrm{cm})$ were based on the mean of measurements collected from five random plants in a plot while grain yield was estimated from cob mass/plot $(\mathrm{kg})$ and later converted to $\mathrm{tha}^{-1}$ after adjusting to $12 \%$ moisture content. Diseases scored included streak, rust, blight, curvularia and infestation of armyworm insects, using a rating of $1-5$, where $1=1-10 \%$ infection, $2=11$ $29 \%$ infection, $3=30-45 \%$ infection, $4=46-60 \%$ infection and $5=61 \%$ and above infection respectively. Data 
Table 1: List of popcorn lines and their source

\begin{tabular}{llll}
\hline S/N & Materials & Grain colour & Source \\
\hline 1. & Small Pearl Shaped & Yellow & IAR\&T \\
2. & Popcorn 2-S0 & Yellow & IAR\&T \\
3. & Popcorn 34-Y & Yellow & IAR\&T \\
4. & Popcorn 37-Y & Yellow & IAR\&T \\
5. & Popcorn 20-Y & Yellow & IAR\&T \\
6. & Popcorn 44-Y & Yellow & IAR\&T \\
7. & Popcorn 32-Y & Yellow & IAR\&T \\
8. & Large Pearl Shaped & Yellow & IAR\&T \\
9. & Popcorn 9-Y & Yellow & IAR\&T \\
10. & Popcorn 66-Y & Yellow & IAR\&T \\
11. & Popcorn 33-1-Y & Yellow & IAR\&T \\
12. & Popcorn 40-Y & Yellow & IAR\&T \\
13. & Popcorn 52-Y & Yellow & IAR\&T \\
14. & Popcorn 36-Y & Yellow & IAR\&T \\
15. & Popcorn 4-Y & Yellow & IAR\&T \\
16. & Popcorn 3-Y & Yellow & IAR\&T \\
17. & Popcorn-18-Y & Yellow & IAR\&T \\
18. & Popcorn-6-Y & Yellow & IAR\&T \\
19. & Eruwa Local $($ Check & Yellow & IAR\&T \\
\hline & & &
\end{tabular}

were also collected on descriptive attributes including the colour of various plant parts such as stem, leaf, mid-rib, leaf blade, anther and silk. Others were broadness of leaves, leaf orientation and nature of anthesis. Palatability and general acceptability ratings were carried out on a scale of $1-5$ where $1=$ excellent, $2=$ very good, $3=$ good, $4=$ fair and $5=$ poor.

Data collected on quantitative characters were subjected to analyses of variance (ANOVA) using SAS version 9.0. Means of attributes for which popcorn lines differ significantly were separated using least significant difference (LSD) as outlined by Steel and Torrie (1980).

The format of Analysis of variance model used can be expressed as follows:

$\mathrm{Y} i j=\mu+\mathrm{E} j+\mathrm{G} i+\mathrm{GE} i j+\mathrm{E} i j k$

Where:

$\mu=$ population mean

$\mathrm{E} j=$ effect of the ith environment

$\mathrm{G} i=$ effect of the jth genotype

GE $i j=$ interaction effect of ith environment and jth treatment

Eijk $=$ error term

\section{RESULTS AND DISCUSSION}

The results of the mean squares from the combined analyses of variance (ANOVA) for agronomic characters in the 19 popcorn lines showed that expression of almost all the characters differed significantly $(\rho \leq 0.01)$ from one location $(\mathrm{L})$ to the other except days to silking and ears/plant while the genotype $(G)$ differed significantly $(\rho \leq 0.01)$ for all the characters except ear aspect and cob length (Table 2). Genotype $x$ Location (GL) interaction on the other hand had a pronounced effect $(\rho \leq 0.01)$ on all the morphological characters measured except cob length, with location showing a greater magnitude of variability in terms of larger mean squares for most of the characters. These results revealed a wide range of variability among the popcorn lines with respect to most of the agronomic traits measured, indicating the possibility of exploiting the existing variation among the lines for improving popcorn population for enhanced yield and other agronomic attributes through selection. The significant G x L interaction for grain yield and some other agronomic traits indicates differences in genotypic performance for these traits from one location to another which may be attributed to differences in environmental conditions of the testing sites. This underscores the necessity for evaluating new genetic materials across a number of environments where they are intended for cultivation to determine more accurately, the genetic potentials under varying environmental conditions and to detect stability and adaptation for proposed ecologies of cultivation.

The significant differences observed among the lines for popping volume indicate the existence of adequate genetic variability for this trait which could be exploited in the development of hybrid varieties for the popcorn industry. In an earlier study, Oz and Kapar (2011) also reported significant difference in popping volume among popcorn genotypes evaluated for three years which is similar to results obtained in this study. In other words, the presence of genetic variability among these lines will give way for effective selection programme to enhance improvement for high popping quality.

Although the results of the mean squares from combined ANOVA for insect and diseases rating showed that the popcorn lines did not differ significantly for diseases and insect rating, however, the effect of prevailing environmental conditions in the two locations was significant $(\rho \leq 0.01)$ for all the parameters except leaf blight and Curvularia leaf spot. G x L effect was also significant for streak $(\rho \leq 0.05)$. The mean values across the locations revealed that the popcorn lines were generally resistant to leaf blight and Curvularia. (Table 3).

Means for agronomic characters of the popcorn lines showed that small pearl shaped was the earliest to mature, recording about 54 days to attain silking while Popcorn $52-\mathrm{Y}$ was the latest to attain maturity, recording 66 days to silking (Table 4). Two other lines (Popcorn 66-Y, Popcorn $4-\mathrm{Y}$ ) were also early maturing while large pearl 
Table 2: Mean squares from combined ANOVA for agronomic characters, grain yield and yield components in 19 popcorn lines

\begin{tabular}{|c|c|c|c|c|c|c|c|c|c|c|}
\hline $\begin{array}{l}\text { Source of varia- } \\
\text { tion }\end{array}$ & df & $\begin{array}{l}\text { Days to } \\
\text { silking }\end{array}$ & Ear height & Husk cover & Ear aspect & Ears/Plant & Cob length & Cob width & $\begin{array}{l}\text { No. of row } \\
\text { cob }\end{array}$ & $\begin{array}{l}\text { / Grain } \\
\text { yield }\end{array}$ \\
\hline Location (L) & 1 & 50.67 & $110548.25^{\star}$ & $\star 54.75^{\star *}$ & $39.38^{\star *}$ & 0.00079 & $251.43^{\star *}$ & $11.12^{\star *}$ & $120.08^{\star *}$ & $3.60^{* *}$ \\
\hline Rep (Env) & 4 & 66.51 & 161.86 & 1.11 & 0.17 & 0.02 & 6.85 & 0.30 & 0.12 & 0.04 \\
\hline Genotype (G) & 18 & $68.49^{* *}$ & $460.88^{\star \star}$ & $1.47^{\star \star}$ & 0.83 & $0.05^{\star *}$ & 7.63 & $0.76^{\star *}$ & $4.73^{\star \star}$ & $1.52^{\star \star}$ \\
\hline $\mathrm{G} \times \mathrm{L}$ & 18 & $37.76^{\star *}$ & $285.14^{\star \star}$ & $1.62^{\star *}$ & $1.60^{\star *}$ & $0.05^{\star *}$ & 6.76 & $0.78^{\star \star}$ & $5.54^{\star \star}$ & $0.26^{\star *}$ \\
\hline Pooled Error & 72 & 13.68 & 62.38 & 0.49 & 0.54 & 0.01 & 5.50 & 0.34 & 2.69 & 0.08 \\
\hline
\end{tabular}

*, ** Significantly different at 0.05 and 0.01 levels of probability respectively

shaped, Popcorn 6-Y and Popcorn 52-Y were the latest highest yielding among the lines across the two locations to attaining maturity. Popcorn 36-Y was the tallest while followed by 'Large Pearl Shaped, Popcorn 40-Y and PopPopcorn 6-Y was the shortest. Popcorn 33-1-Y was the corn 34-Y, while the poorest for grain yield was 'Eruwa'

Table 3: Mean performance (across location) for insect and disease rating of 19 popcorn lines and check

\begin{tabular}{|c|c|c|c|c|c|}
\hline Popcorn lines & Streak (1-5) & Rust (1-5) & Blight (1-5) & Curvularia (1-5) & Armyworm (1-5) \\
\hline Popcorn 44-Y & 2.33 & 1.67 & 1.00 & 1.00 & 1.33 \\
\hline Popcorn 18-Y & 3.17 & 2.00 & 1.00 & 1.00 & 1.00 \\
\hline Popcorn 9-Y & 2.50 & 2.00 & 1.00 & 1.00 & 1.00 \\
\hline Popcorn 34-Y & 1.83 & 1.83 & 1.00 & 1.00 & 1.17 \\
\hline Popcorn 4-Y & 2.83 & 1.83 & 1.00 & 1.00 & 1.00 \\
\hline Popcorn 66-Y & 2.17 & 1.50 & 1.00 & 1.00 & 1.33 \\
\hline Small Pearl Shaped & 2.67 & 1.83 & 1.00 & 1.00 & 1.17 \\
\hline Popcorn 40-Y & 2.83 & 1.67 & 1.00 & 1.00 & 1.17 \\
\hline Popcorn 20-Y & 1.83 & 1.83 & 1.33 & 1.17 & 1.17 \\
\hline Large Pearl Shaped & 2.83 & 2.17 & 1.00 & 1.00 & 1.00 \\
\hline Popcorn 2-So & 2.33 & 1.83 & 1.00 & 1.00 & 1.33 \\
\hline Popcorn 3-Y & 2.83 & 1.83 & 1.00 & 1.00 & 1.00 \\
\hline Popcorn 32-Y & 2.67 & 1.67 & 1.00 & 1.00 & 1.00 \\
\hline Popcorn 37-Y & 2.33 & 1.83 & 1.00 & 1.00 & 1.17 \\
\hline Popcorn 33-1-Y & 2.67 & 1.50 & 1.00 & 1.00 & 1.17 \\
\hline Popcorn 6-Y & 2.00 & 1.50 & 1.00 & 1.00 & 1.00 \\
\hline Popcorn 52-Y & 2.83 & 2.00 & 1.00 & 1.00 & 1.17 \\
\hline Popcorn 36-Y & 2.17 & 2.00 & 1.00 & 1.00 & 1.17 \\
\hline Eruwa local (check) & 3.00 & 1.83 & 1.00 & 1.00 & 1.00 \\
\hline Mean & 2.57 & 1.81 & 1.02 & 1.03 & 1.12 \\
\hline \multicolumn{6}{|l|}{ F-Test } \\
\hline Location (L) & $112.01^{\star *}$ & $48.04^{* *}$ & 0.04 & 0.08 & $1.72^{\star *}$ \\
\hline Genotype (G) & 1.12 & 0.21 & 0.04 & 0.04 & 0.09 \\
\hline $\mathrm{G} \times \mathrm{L}$ & $1.29^{*}$ & 0.33 & 0.04 & 0.04 & 0.09 \\
\hline Pooled Error & 0.67 & 0.26 & 0.04 & 0.04 & 0.12 \\
\hline $\mathrm{CV} \%$ & 31.77 & 28.44 & 18.41 & 19.95 & 31.09 \\
\hline LSDa0.05 & 0.96 & 0.59 & 0.22 & 0.24 & 0.40 \\
\hline
\end{tabular}

* ** Significantly different at 0.05 and 0.01 levels of probability respectively 
Table 4: Mean Performance for agronomic characters, grain yield and yield components in 19 Popcorn lines and check

\begin{tabular}{|c|c|c|c|c|c|c|c|c|c|}
\hline Popcorn Lines & $\begin{array}{l}\text { Days to } 50 \\
\% \text { silking }\end{array}$ & $\begin{array}{l}\text { Ear height } \\
(\mathrm{cm})\end{array}$ & $\begin{array}{l}\text { Husk cover } \\
(1-5)\end{array}$ & $\begin{array}{l}\text { Ear aspect } \\
(1-5)\end{array}$ & $\begin{array}{l}\text { Ears/plant } \\
\text { (no) }\end{array}$ & $\begin{array}{l}\text { Cob Length } \\
(\mathrm{cm})\end{array}$ & $\begin{array}{l}\text { Cob Width } \\
(\mathrm{cm})\end{array}$ & $\begin{array}{l}\text { No. of rows/ } \\
\text { cob (no) }\end{array}$ & $\begin{array}{l}\text { Grain yield } \\
\left(\mathrm{t} \mathrm{ha}^{-1}\right)\end{array}$ \\
\hline Popcorn 44-Y & 62 & 86 & 3 & 3 & 1 & 14 & 7 & 13 & 1.50 \\
\hline Popcorn 18-Y & 60 & 76 & 3 & 4 & 1 & 16 & 7 & 12 & 1.27 \\
\hline Popcorn 9-Y & 62 & 90 & 3 & 3 & 1 & 14 & 8 & 14 & 1.57 \\
\hline Popcorn 34-Y & 57 & 101 & 3 & 3 & 1 & 16 & 7 & 13 & 2.15 \\
\hline Popcorn 4-Y & 55 & 87 & 3 & 3 & 1 & 15 & 7 & 13 & 1.55 \\
\hline Popcorn 66-Y & 54 & 78 & 2 & 3 & 1 & 18 & 8 & 13 & 1.85 \\
\hline Small Pearl Shaped & 54 & 73 & 4 & 3 & 1 & 14 & 7 & 13 & 1.05 \\
\hline Popcorn 40-Y & 58 & 95 & 2 & 2 & 1 & 14 & 7 & 12 & 2.36 \\
\hline Popcorn 20-Y & 61 & 80 & 3 & 3 & 1 & 14 & 7 & 15 & 1.53 \\
\hline Large Pearl Shaped & 63 & 84 & 2 & 3 & 1 & 17 & 7 & 13 & 2.48 \\
\hline Popcorn 2-So & 55 & 90 & 2 & 3 & 1 & 15 & 8 & 14 & 1.18 \\
\hline Popcorn 3-Y & 58 & 80 & 2 & 4 & 1 & 14 & 8 & 13 & 1.77 \\
\hline Popcorn 32-Y & 58 & 83 & 3 & 4 & 1 & 15 & 8 & 15 & 1.16 \\
\hline Popcorn 37-Y & 56 & 82 & 3 & 4 & 1 & 15 & 7 & 13 & 1.05 \\
\hline Popcorn 33-1-Y & 58 & 101 & 3 & 3 & 1 & 17 & 8 & 14 & 2.61 \\
\hline Popcorn 6-Y & 63 & 75 & 3 & 3 & 1 & 15 & 8 & 13 & 1.13 \\
\hline Popcorn 52-Y & 66 & 85 & 4 & 3 & 1 & 15 & 7 & 15 & 1.46 \\
\hline Popcorn 36-Y & 59 & 102 & 3 & 3 & 1 & 14 & 7 & 13 & 1.91 \\
\hline Eruwa local (check) & 60 & 89 & 3 & 4 & 1 & 14 & 7 & 14 & 1.01 \\
\hline Mean & 58.70 & 86.16 & 2.69 & 3.20 & 3.20 & 15.07 & 7.42 & 13.33 & 1.61 \\
\hline CV \% & 6.30 & 9.17 & 26.09 & 22.88 & 22.58 & 15.56 & 7.80 & 12.30 & 17.04 \\
\hline LSD $\propto 0.05$ & 4.48 & 9.14 & 0.82 & 0.83 & 0.12 & 2.71 & 0.66 & 1.86 & 0.31 \\
\hline
\end{tabular}

local (check). The relatively low grain yield recorded for small pearl shaped, Popcorn lines 66-Y, 4-Y, 2-S and '37$\mathrm{Y}$ ' may not be unconnected with earliness in maturity. However, line '66-Y' combined earliness with average grain yield indicating that this line is a promising candidate for further testing or as parent in a hybridization programme.

Popcorn 33-1-Y gave the highest yield with a yield advantage of $38.7 \%$ over the reference check ('Eruwa' local) with mean yield of $1.01 \mathrm{tha}^{-1}$, but with the lowest popping volume of $866.7 \mathrm{~cm}^{3}$ On the other hand, the lowest yielding line ('Eruwa' local) had a popping volume of $2590 \mathrm{~cm}^{3}$, ranking $4^{\text {th }}$ among the 19 popcorn lines evaluated for popping potential. This suggests that popping expansion is inversely proportional to grain yield, which corroborates the findings of several authors who reported a negative association between grain yield of popcorn and popping volume (Dofing et al., 1991; Burak and Broccoli, 2001; Vijayabharathi et al., 2009). The implication of this is that the two important traits will be difficult to improve simultaneously. The use of molecu- lar breeding approach might therefore be the best option in this situation, where the QTLs for popping expansion and grain yield can be mapped, followed by selection for yield while DNA markers can be used to retain favourable alleles for popping expansion.

Hussain et al., (2010) described grain yield as a combined outcome of the inherent genetic potential and the interaction of genotype with the environment, therefore interactive means of $\mathrm{G} \times \mathrm{L}$ effect for grain yield and ears per plant are presented in Table 5. The lines changed rank for grain yield from one location to the other with Popcorn 36-Y, Popcorn 18-Y, Popcorn 34-Y and 'Large Pearl Shaped' being largely responsible for the significant $\mathrm{G} \times \mathrm{L}$ effect for this trait. This shows that grain yield was found to be genetically diverse as a result of its significant differences when character means were combined across the two environments. Most of the lines performed better in Ibadan compared to Ikenne with respect to grain yield except for three lines (Popcorn 9-Y, Popcorn 4-Y and Popcorn 6-Y). However, Popcorn lines 9-Y, 6-Y, $40-\mathrm{Y}$ and $37-\mathrm{Y}$ exhibiting similar performance in terms 
Table 5: Interactive effect of Location by Genotype for grain yield and ears/plant

\begin{tabular}{|c|c|c|c|c|c|c|c|c|}
\hline \multicolumn{5}{|l|}{ Grain Yield } & \multicolumn{4}{|c|}{ Ears/plant } \\
\hline Popcorn lines & Ibadan & Ikenne & $\sum \mathrm{RSI}$ & Rank & Ibadan & Ikenne & $\sum \mathrm{RSI}$ & Rank \\
\hline Popcorn 44-Y & $1.70(9)$ & $1.31(11)$ & 20 & $9^{\text {th }}$ & $1.11(6)$ & $1.06(2)$ & 8 & $1^{\text {st }}$ \\
\hline Popcorn 18-Y & $1.60(11)$ & $0.94(17)$ & 28 & $12^{\text {th }}$ & $1.11(7)$ & $1.00(4)$ & 11 & $2^{\text {nd }}$ \\
\hline Popcorn 9-Y & $1.57(12)$ & $1.57(8)$ & 20 & $9^{\text {th }}$ & $0.75(18)$ & $1.00(6)$ & 24 & $12^{\text {th }}$ \\
\hline Popcorn 34-Y & $2.60(3)$ & $1.70(4)$ & 7 & $4^{\text {th }}$ & $1.08(9)$ & $1.00(7)$ & 16 & $8^{\text {th }}$ \\
\hline Popcorn 4-Y & $1.47(13)$ & $1.63(7)$ & 20 & $8^{\text {th }}$ & $1.12(5)$ & $1.00(8)$ & 13 & $5^{\text {th }}$ \\
\hline Popcorn 66-Y & $1.95(6)$ & $1.74(3)$ & 9 & $5^{\text {th }}$ & $1.23(2)$ & $1.00(9)$ & 11 & $2^{\text {nd }}$ \\
\hline Small Pearl Shaped & $1.19(16)$ & $0.91(18)$ & 34 & $16^{\text {th }}$ & $0.91(14)$ & $1.07(1)$ & 15 & $7^{\text {th }}$ \\
\hline Popcorn $40-\mathrm{Y}$ & $2.42(4)$ & $2.31(2)$ & 6 & $2^{\text {nd }}$ & $1.14(4)$ & $1.00(10)$ & 14 & $6^{\text {th }}$ \\
\hline Popcorn 20-Y & $1.71(8)$ & $1.34(10)$ & 18 & $8^{\text {th }}$ & $0.96(13)$ & $0.93(19)$ & 32 & \\
\hline Large Pearl Shaped & $3.31(1)$ & $1.64(5)$ & 6 & $2^{\text {nd }}$ & $0.90(15)$ & $1.00(11)$ & 26 & $13^{\text {th }}$ \\
\hline Popcorn 2-So & $1.25(14)$ & $1.11(14)$ & 28 & $12^{\text {th }}$ & $0.68(19)$ & $1.00(12)$ & 31 & $17^{\text {th }}$ \\
\hline Popcorn 3-Y & $1.89(7)$ & $1.64(6)$ & 13 & $6^{\text {th }}$ & $0.82(16)$ & $1.00(13)$ & 29 & $15^{\text {th }}$ \\
\hline Popcorn 32-Y & $1.23(15)$ & $1.09(15)$ & 30 & $14^{\text {th }}$ & $1.15(3)$ & $1.00(14)$ & 17 & $9^{\text {th }}$ \\
\hline Popcorn 37-Y & $1.10(19)$ & $1.00(16)$ & 35 & $17^{\text {th }}$ & $0.78(17)$ & $1.00(15)$ & 32 & $18^{\text {th }}$ \\
\hline Popcorn 33-1-Y & $2.76(2)$ & $2.46(1)$ & 3 & $1^{\text {st }}$ & $1.37(1)$ & $1.00(16)$ & 17 & $9^{\text {th }}$ \\
\hline Popcorn 6-Y & $1.12(18)$ & $1.13(13)$ & 31 & $15^{\text {th }}$ & $1.09(8)$ & $1.06(3)$ & 11 & $2^{\text {nd }}$ \\
\hline Popcorn 52-Y & $1.64(10)$ & $1.28(12)$ & 22 & $11^{\text {th }}$ & $0.99(11)$ & $0.97(18)$ & 29 & $15^{\text {th }}$ \\
\hline Popcorn 36-Y & $2.27(5)$ & $1.55(9)$ & 14 & $7^{\text {th }}$ & $1.04(10)$ & $1.00(17)$ & 27 & $14^{\text {th }}$ \\
\hline Eruwa local (check) & $1.17(17)$ & $0.84(19)$ & 36 & $18^{\text {th }}$ & $0.96(12)$ & $1.00(5)$ & 17 & $9^{\text {th }}$ \\
\hline LSD $a 0.05$ & & 0.10 & & & & 0.04 & & \\
\hline
\end{tabular}

${ }^{*},{ }^{*}$ Significantly different at 0.05 and 0.01 levels of probability, respectively

of grain yield at the two locations can be considered to be relatively stable across these locations compared to other popcorn lines. This superiority of performance may be attributed to efficient irrigation system enjoyed by the plants in Ibadan compared to Ikenne during the evaluation exercise. Similarly, occurrence of streak was very predominant in Ikenne compared to Ibadan, which also might have contributed to the low grain yield recorded in Ikenne. Moreover, Ikenne is a hot spot for maize foliar diseases because of its hot humid nature which favours sporulation and accumulation of different kinds of disease inoculums. Similarly, streak transmitting vectors (Cicadulina spp.) is prevalent in Ikenne thereby lending itself as screening site by many maize scientists. Lukuyu et al., (2002) in their study, reported the negative impact of maize streak virus on grain yield and seed quality of maize. In an earlier report, Bosque-Perez et al., (1998) studying the effect of maize streak virus disease on the growth and yield of maize reported that varieties differed significantly in the amount of loss, disease severity and incidence, which can also be related to this study. $G x$
L effect for ears per plant showed that Popcorn 33-1-Y, Popcorn 32-Y, 'Small Pearl', Popcorn 9-Y, Popcorn 66-Y and Popcorn 40-Y were responsible for the significant interaction between genotype and location, due to the wide range observed in their ranking between the two locations.

The popcorn lines differed significantly $(\rho \leq 0.01)$ with respect to general acceptability, popping volume and expansion ratio but not for 100-grain mass, taste and flavor (Table 6). Mean performance for popping characters and acceptability ratings revealed that small pearl shaped had the largest popping expansion followed by Popcorn $20-Y$ while the lowest popping volume of $73.3 \mathrm{~cm}^{3}$ was recorded for Popcorn 3-Y. Similarly, the largest expansion ratio was recorded for small pearl shaped followed by Popcorn 20-Y while Popcorn 3-Y gave the smallest expansion ratio. Popcorn 18-Y was rated best for taste among the 19 popcorn lines while Popcorn 3-Y was the least. Popcorn 4-Y and Popcorn 36-Y were the best for flavor while Popcorn 32-Y was the poorest. Similarly, Popcorn 9-Y and Popcorn 3-Y. Popcorn 44-Y, Popcorn 
Table 6: Mean performance for popping ability and consumer acceptability ratings of 19 popcorn lines

\begin{tabular}{|c|c|c|c|c|c|c|}
\hline Popcorn lines & $\begin{array}{l}\text { 100-grain mass } \\
(\mathrm{kg})\end{array}$ & $\begin{array}{l}\text { Popping Volume } \\
\left(\mathrm{cm}^{3}\right)\end{array}$ & $\begin{array}{l}\text { Expansion Ratio } \\
\left(\mathrm{cm}^{3} \mathrm{~kg}^{-1}\right)\end{array}$ & $\begin{array}{l}\text { Taste } \\
(1-5)\end{array}$ & $\begin{array}{l}\text { Flavour } \\
(1-5)\end{array}$ & $\begin{array}{l}\text { General ac- } \\
\text { ceptability }\end{array}$ \\
\hline Popcorn 44-Y & 0.01 & 1340.0 & 10308 & 2 & 2 & 2 \\
\hline Popcorn 18-Y & 0.02 & 1190.0 & 9154 & 1 & 2 & 2 \\
\hline Popcorn 9-Y & 0.02 & 930.0 & 7154 & 2 & 3 & 3 \\
\hline Popcorn 34-Y & 0.01 & 1516.7 & 11667 & 2 & 2 & 2 \\
\hline Popcorn 4-Y & 0.01 & 2766.7 & 21282 & 2 & 2 & 2 \\
\hline Popcorn 66-Y & 0.02 & 2040.0 & 15692 & 2 & 3 & 3 \\
\hline Small Pearl Shaped & 0.01 & 3080.0 & 23692 & 3 & 2 & 3 \\
\hline Popcorn 40-Y & 0.02 & 836.7 & 6436 & 2 & 3 & 3 \\
\hline Popcorn 20-Y & 0.01 & 2830.0 & 21769 & 2 & 2 & 2 \\
\hline Large Pearl Shaped & 0.02 & 14.96 .7 & 11513 & 2 & 2 & 2 \\
\hline Popcorn 2-So & 0.01 & 2370.0 & 18231 & 2 & 3 & 3 \\
\hline Popcorn 3-Y & 0.02 & 73.3 & 564 & 3 & 3 & 3 \\
\hline Popcorn 32-Y & 0.01 & 1670.0 & 12846 & 3 & 3 & 3 \\
\hline Popcorn 37-Y & 0.01 & 1836.7 & 14128 & 2 & 3 & 2 \\
\hline Popcorn 33-1-Y & 0.02 & 866.7 & 6667 & 3 & 3 & 3 \\
\hline Popcorn 6-Y & 0.01 & 1776.7 & 13667 & 2 & 3 & 3 \\
\hline Popcorn 52-Y & 0.01 & 2546.7 & 19590 & 2 & 2 & 2 \\
\hline Popcorn 36-Y & 0.01 & 1526.7 & 11744 & 2 & 2 & 2 \\
\hline Eruwa local (check) & 0.02 & 2590.0 & 19923 & 3 & 3 & 3 \\
\hline Mean & 0.02 & 1751.75 & 13475.03 & 2.32 & 2.54 & 2.56 \\
\hline \multicolumn{7}{|l|}{ F-Test } \\
\hline Genotype (G) & $0.13 \times 10^{-4}$ & $1923419.88^{\star \star}$ & $113811827^{\star \star}$ & 0.39 & 0.34 & $0.45^{\star}$ \\
\hline Error & $0.81 \times 10^{-5}$ & 31813.74 & 1882470 & 0.22 & 0.24 & 0.24 \\
\hline CV\% & 19.60 & 10.18 & 10.18 & 20.31 & 19.33 & 18.96 \\
\hline LSDa0.05 & 0.005 & 295.36 & 2272 & 0.78 & 0.81 & 0.80 \\
\hline
\end{tabular}

*, ** Significantly different at 0.05 and 0.01 levels of probability, respectively

34-Y and Popcorn 4-Y were rated to be the best for general acceptability while Popcorn $32-Y$ was rated to be the least acceptable popcorn lines.

\section{CONCLUSION}

Five of the popcorn lines (small pearl shaped, Popcorn 66-Y, Popcorn 4-Y, Popcorn 2-S and Popcorn 37$\mathrm{Y})$ were early maturing and so could be utilized to develop source population for inbred line extraction for the formation of early maturing popcorn hybrid. Four other lines (Popcorn 33-1-Y, large pearl shaped, Popcorn 40-Y and Popcorn 34-Y) expressed high yield potential (2.0 $\mathrm{t} \mathrm{ha}^{-1}$ ) while another seven ('Small Pearl', 'Eruwa' local, Popcorn 4-Y, Popcorn 66-Y, Popcorn 20-Y, Popcorn 2-S and Popcorn 52-Y) expressed large popping volume of over $2000 \mathrm{~cm}^{3}$. These materials therefore look promising as parents for the development of future commercial hybrid popcorn for tropical and sub-tropical agro-ecology.

\section{REFERENCES}

Acquaah, G. (2007). Principles of Plant Genetics and Breeding. UK: BLACKWELL.

Ashman, R.B. (1991). Registration of three popcorn (maize) parental lines HP62-02, HP72-11 and Hp 68- 07. Crop Science, 315, 1402-1403. https://doi.org/10.2135/cropsci1991. 0011183X003100050100x

Bosque-Perez, N., Olojede, S. \& Buddenhagen, I. (1998). Effect of Maize Streak Virus disease on the growth and yield of maize as influenced by varietal resistance levels and plant stage at time of challenge. Euphytica, 101, 307. https://doi. org/10.1023/A:1018345921770 
Broccoli, A.M. \& Burak, R. (2004). Effects of genotype $\times$ environment interactions in popcorn maize yield and grain quality. Spanish Journal of Agricultural Research, 2, 85-91. https://doi.org/10.5424/sjar/2004021-64

Derera, J., Phumelele, J. \& Muthulisi, S. (2014). Assessment of popping ability of new tropical popcorn hybrids. Australian Journal of Crop Science, 8, 831-839.

Gökmen, S. (2004). Effects of moisture content and popping method on popping characteristics of popcorn. Journal of Food Engineering, 65, 357-362. https://doi.org/10.1016/j. jfoodeng.2004.01.034

Hussain, N., Qamar-ur-Zaman, M., Amjad, N. \& Abdul, A. (2010). Response of maize varieties under agro-ecological conditions of deraismail khan. Journal of Agricultural Research, 48(1), 59-63.

Iken, J.E. (1993). Popcorn Production and Utilization. In Fakorede, M.A., Alofe, O.O. and Kim, S.K. (eds). Maize Improvement Production and Utilization in Nigeria.

Lukuyu, B.A., Murdoch, A.J., McLeod, A. \& Doward, P. (2002). The impact of Maize streak virus disease on quality and yield of maize forage outputs of the maize-dairy production systems in central highlands of Kenya. Output of Research project R7955; Livestock Production Programme.

Mani, H. \& Dadari, S.A. (2003). Growth and yield analysis of irrigated popcorn (Zea mays everta) grown in Kadawa as affected by sowing date and intra-row spacing using correlation co-efficient. ASSET - Series A: Agriculture \& Environment, 3, 63-70.

Obajimi, A.O., Adenle, V. \& Salami, A. (1996). Incidence, distribution and control of maize downy mildew in South Western Nigeria. In: 1998 Report of the in-house review of the Inst. of Agric. Res. and Training, Ibadan. Nigeria. Pp 39-42.

Olakojo, S.A. \& Iken, J.E. (2002). Development of popcorn va- rieties for high grain yield and adaptation. ASSET - Series A: Agriculture \& Environment, 2, 63-68.

Olakojo, O.O. (2016). Genotypic and agronomic performance of drought tolerant yellow quality protein maize hybrid maize (Zea mays L.) in savanna agro-ecologies of southwestern Nigeria. Nigerian Journal of Genetics, 31, 54-64.

Omidiji, M.O., Kogbe J.O.S., Shoyinka, S.A., Olunuga, B.A., Salawu, R.A. \& Somuji, O. (1992). Striga on maize in Ogun State Nigeria. Maize newsletter. Pp. 1-2

Phumelele, J. (2012). Genetic analysis of agronomic and quality trait in popcorn hybrids: Development of popcorn breeding. M.Sc thesis, University Of KwaZulu-Natal, Pietermaritzburg, South Africa.

Rangel, R.M., Amaral Júnior do, A.T., Scapim, C.A., Freitas Júnior, S.P. \& Pereira, M.G. (2008). Genetic parameters in parents and hybrids of circulant diallel in popcorn. Genetics and Molecular Research, 7, 1020-1030. https://doi. org/10.4238/vol7-4gmr502

Sakın, M.A., Gokmen, S., Yildirim, A., Belen, S. \& Kandemır, N. (2005). Effects of cultivar type on yield and quality of popcorn (Zea mays everta). New Zealand Journal of Crop and Horticultural Science, 33, 17-23. https://doi.org/10.108 0/01140671.2005.9514326

Steel, R.G.D. \& Torrie, J.H. (1980). Principle and procedures of statistics, New York: McGraw-Hill Books Co.

Ziegler, K.E., Ashman, R.B. White, G.M. \& Wysong, D.B. (1984). Popcorn Production and Marketing. Cooperative Extension, Purdue University. USA.

Ziegler, K.E. (2001). Popcorn. In: Hallauer, A.R., (editor) Specialty Corns. CRC Press, USA. pp. 199-234. https://doi. org/10.1201/9781420038569.ch7 